\title{
A Case Study Of The Environmental IMPACT ASSESSMENT LEGISLATIONS IN SARAWAK, MALAysia
}

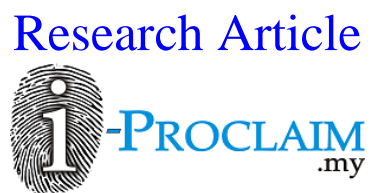

\section{Daniel Tang Kuok Ho}

Asia Pac. j. energy environ.

Department of Petroleum Engineering, Faculty of Engineering and Science, Curtin University Sarawak, 98009, Miri, Sarawak, MALAYSIA

Email for Correspondence: daniel.tang@ curtin.edu.my

Manuscript Received: 30 December 2019

Revised: 01 April 2020

Accepted: 16 April 2020

Abstract

Environmental Impact Assessment (EIA) is a planning tool used to identify, predict, evaluate and mitigate the environmental effects of development projects. In Sarawak, EIA is governed by the both the State and the Federal EIA Orders. This leads to ambivalence in determining the legislation under which a prescribed activity demanding an EIA falls. This case study aims to investigate the implications associated with the coexistence of both EIA Orders in the state of Sarawak from the viewpoints of practicing environmental consultants. The case study reviews the EIA legislations governing EIA practices in the State and includes a qualitative survey involving practicing EIA consultants to gather feedback on the implications associated with the EIA practices and recommendations to resolve the problems identified. The study shows that even though a prescribed activity is defined by the EIA legislations, different stages of the prescribed activity eventually become prescribed activities on their own, which demand fulfillment of different EIA legislation. Unclear demarcation of EIA jurisdiction and different requirements on the scope of an EIA particularly for earthworks also contribute to doubts among environmental consultants interviewed. Consultation, involvement and effective communication with environmental protection as priority are crucial to minimize any uncertainty resulted from co-implementation of both the EIA legislations. Future study can look into comparing perceptions on the effectiveness of the State and the Federal EIA legislations. The case study delves into a crucial issue related to EIA practices in Sarawak, Malaysia which has persisted without being formally addressed in any previous studies.

Key words

Environmental impact assessment, legislations, Department of Environment, NREB, Sarawak, Malaysia

This article is is licensed under a Creative Commons Attribution-NonCommercial 4.0 International License.

Attribution-Non Commercial (CC BY-NC) license lets others remix, tweak, and build upon work non-commercially, and although the new works must also

acknowledge \& be non-commercial.

\section{INTRODUCTION}

Environmental impact assessment (EIA), according to the IAIA (1999, pp. 2), is 'the process of identifying, predicting, evaluating and mitigating the biophysical, social and other relevant effects of development proposals prior to major decisions being taken and commitment made'. The emergence of EIA is closely tied to increasing environment awareness in the 1960s. It assumed legal status in the United States in 1969 when the National Environmental Policy Act (NEPA) was enacted. Since then, EIA has been increasingly adopted as a planning tool globally to aid sound decision-making (Canter, 1995).

In Malaysia, EIA is governed by Section 34A, Environmental Quality Act (EQA) 1974. The Environmental Quality (Prescribed Activities) (Environmental Impact Assessment) 2015 is made under EQA 1974 to provide specific legislative requirements concerning EIA, with reference to the NEPA. Department of Environment (DOE) as the custodian of EQA 1974, is mandated to implement the EIA processes and other requirements thereunder such as licensing (Briffett et al., 2004). Prior to the enactment of EQA 1974, EIAs were conducted on a voluntary basis with reports ranging from water resources to sewage treatment facilities submitted to the relevant authority (Ho, 1986). 
Submission of EIA for prescribed activities became a legal requirement after EQ (Prescribed Activities) (Environmental Impact Assessment) Order 1987 came into force. The scope and depth of an EIA are defined by the nature and extent of the corresponding development project as well as the characteristics of the project site, which subsequently dictate the type of EIA to be submitted to the DOE (DOE, 2007). There are two types of EIA under the DOE, i.e. preliminary and detailed. The 'EIA Procedure and Requirements' in Malaysia published by DOE specified the types of project requiring detailed EIA before 2015. The types of EIA to be submitted were also subject to the discretion of the Director General of DOE (DOE, 2007). In 2015, the EQ (Prescribed Activities) (Environmental Impact Assessment) Order 1987 was revoked and replaced by the Environmental Quality (Prescribed Activities) (Environmental Impact Assessment) Order 2015. All activities under First Schedule of the new Order demand Preliminary EIA while activities under Second Schedule of the new Order demand Detailed EIA.

DOE is the sole environmental authority in all states of Malaysia except Sabah and Sarawak, where the respective state environmental authorities coexist with the DOE (Emang, 2006). In Sarawak, inclusion of environmental aspect in the Colonial Natural Resources Ordinance 1949 led to the formation of the present Natural Resources and Environment Ordinance (NREO) 1993, which prompts the establishment of the state environmental agency known as the Natural Resources and Environment Board (NREB) as custodian of the Ordinance (Emang, 2006). Sabah later enacted the state environmental legislation named the Conservation of Environment Enactment 1996 which gives rise to the Environmental Protection Department (Moduying, 2001; Sentian, 2004).

In Sarawak, EIA processes are subject to both the Federal and State environmental legislations. The limits of constitutional power of both legislations are defined by the Ninth Schedule of the Federal Constitution (Mamit, 1997). The Federal EIA Order 1987 provides for exclusion of prescribed activities listed in the First Schedule of the Natural Resources and Environment (Prescribed Activities) Order 1994 (NREB, 1994). However, a clause stating such exclusion is not stipulated in the new Federal EIA Order 2015. Despite demarcation of the Federal and State jurisdiction in EIA processes, the requirements are not often clear-cut and occasionally, separate EIAs addressing similar aspects of a prescribed activity need to be conducted to meet the Federal and State EIA requirements, respectively. For instance, EIA for the development of industrial facilities are under the governance of the DOE but the associated land-clearing and earthworks during site preparation fall under the jurisdiction of the NREB. Nonetheless, it is common for the former to have addressed certain extent of site preparation, leading to redundancy in the process (Memon, 2000; Briffett et al., 2004). Therefore, it is important to review and gather perceptions concerning the implications of having both the Federal and State EIA legislations implemented within Sarawak to obtain better picture of their effectiveness and contribute towards better harmonization of the federal and state EIA requirements in Sarawak.

\section{ENVIRONMENTAL LEGISLATIONS}

The DOE and the NREB, as the Federal and State environmental authorities respectively, define their prescribed activities in the EQ (Prescribed Activities) (Environmental Impact Assessment) Order 2015 and the Natural Resources and Environment (Prescribed Activities) Order 1994 successively. Examination of both Orders show similar prescribed activities as shown in Table 1.

Table 1: Comparison of prescribed activities under the DOE and the NREB

\begin{tabular}{|l|l|}
\hline $\begin{array}{l}\text { Natural Resources and Environment (Prescribed } \\
\text { Activities) Order 1994 }\end{array}$ & $\begin{array}{c}\text { Environmental Quality (Prescribed Activities) } \\
\text { (Environmental Impact Assessment) Order 2015 }\end{array}$ \\
\hline Authority: NREB & Authority: DOE \\
\hline - Agriculture development & $\bullet$ Agriculture \\
\hline$\bullet$ Logging & $\bullet$ Forestry \\
\hline $\begin{array}{l}\text { Development of commercial, industrial and } \\
\text { housing estates }\end{array}$ & $\bullet$ Housing \\
\hline $\begin{array}{l}\text { Activities which may pollute inland water or affect } \\
\text { sources of water supply }\end{array}$ & $\bullet$ Construction of dam \\
& $\bullet$ Dater supply \\
\hline $\begin{array}{l}\text { Fisheries and activities which may endanger } \\
\text { marine or aquatic life, plants in inland waters or }\end{array}$ & $\bullet$ Fisheries \\
\hline
\end{tabular}




\begin{tabular}{|c|c|}
\hline erosion of river banks & \\
\hline $\begin{array}{l}\text { - Extraction and removal of rock materials and } \\
\text { mining }\end{array}$ & $\begin{array}{l}\text { - } \text { Mining* } \\
\text { - } \text { Petroleum } \\
\text { - } \text { Quarries } \\
\end{array}$ \\
\hline - Facilities for disposal and treatment of waste & - Waste treatment and disposal \\
\hline $\begin{array}{l}\text { - Any other activities which may damage or have an } \\
\text { adverse impact on the quality of environment or } \\
\text { natural resources of the state }\end{array}$ & $\begin{array}{l}\text { - Infrastructure } \\
\text { - Ports } \\
\text { - Aerodrome } \\
\text { - Power generation and transmission } \\
\text { - Railways } \\
\text { - Transportation } \\
\text { - Resort and recreational development } \\
\text { - Development in coastal and hill area } \\
\text { - Development in coastal area, national park and } \\
\text { - } \text { state park }\end{array}$ \\
\hline & $\begin{array}{ll}\text { - } & \text { Industry } \\
\text { - } & \text { Radioactive materials and radioactive waste }\end{array}$ \\
\hline
\end{tabular}

*Mining can fall under two different classes of prescribed activities under the Natural Resources and Environment (Prescribed Activities) Order 1994

There is an apparent difference between the prescribed activities under both Orders. The State EIA Order adopts an inclusive approach with a list of broadly defined prescribed activities while the Federal EIA Order has a more specific approach with specific prescribed activities (DOE, 2011; NREB, 1995). A direct matching between the prescribed activities defined by both legislations is not straightforward. For instance the Environmental Quality (Prescribed Activities) (Environmental Impact Assessment) Order 2015 explicitly requires preliminary EIA for mining activities encompassing ore processing outside tenement area, including 1) concentrating of aluminium, copper, iron, tantalum or rare earth element, 2) sand mining on land or river or in coastal area or in territorial waters not exceeding 3 nautical miles measured from the low-water line, involving an area of 20 ha or more and 3) sand mining in continental shelf area. Nonetheless, under the State EIA Order, mining and sand extraction falls under the category of 'activities which may pollute inland water or affect sources of water supply' which also includes water supply, irrigation schemes and aquaculture development (NREB, 1994).

The DOE also makes a distinction between activities requiring preliminary and detailed EIA based on quantum and project size primarily (DOE, 2007). Taking mining for instance, while the above-mentioned prescribed activities demand preliminary EIA, detailed EIA is required for mining of minerals in new areas involving large scale operation and mining of minerals within or adjacent to or near environmentally sensitive area. Sand mining prescribed by the DOE is equivalent to diversion of watercourses, streams or rivers or the excavation of sand and other rock materials therefrom prescribed by the Natural Resources and Environment (Prescribed Activities) Order 1994. The State EIA Order does not specify its requirement on ore processing as in the Federal EIA Order but this can probably be matched to the all-inclusive prescribed activity spelling "the clearing of vegetation on any land or the breaking up of any land for any purpose of an area exceeding 50 hectares" (NREB, 1994).

In view of this, the inclusive approach of NREB's prescribed activities require higher degree of interpretative effort by the EIA consultants (Mamit, 1997). In addition, the State EIA Order does not have explicit requirement of petroleum exploration and development, which confers the DOE the direct jurisdiction for such activities off the coast of Sarawak.

Prescribed activities under the category of power generation and transmission in the Federal EIA Order is mapped with comparable prescribed activities in the State EIA Order as shown in Table 2. The State EIA Order, in general, lacks specific requirements in relation to power generation and transmission. In 2015, DOE separates hydropower development from power generation and transmission to a new category of prescribed activities under Second Schedule of its EIA Order, called construction of dam. Prescribed activities in this category comprise construction of dam for the purpose of irrigation, flood mitigation, recreation and water supply as well as hydro-electric power scheme. The State EIA Order, though having provision for 'construction of dams, artificial lakes or reservoir with a surface area of 50 ha for impounding of water', does not iterate specific requirement in relation to hydropower scheme (NREB, 1994). 
Table 2: Mapping of prescribed activities under power generation and transmission in the Federal EIA Order to comparable prescribed activities in the State EIA Order

\begin{tabular}{|c|c|}
\hline $\begin{array}{c}\text { Environmental Quality (Prescribed Activities) } \\
\text { (Environmental Impact Assessment) Order } 2015\end{array}$ & $\begin{array}{c}\text { Natural Resources and Environment (Prescribed } \\
\text { Activities) Order } 1994\end{array}$ \\
\hline 13. Power Generation and Transmission (First Schedule) & $\begin{array}{l}\text { 7. Any other activities which may damage or have an } \\
\text { adverse impact on quality of environment or natural } \\
\text { resources of the State }\end{array}$ \\
\hline $\begin{array}{l}\text { Construction of steam generated power stations } \\
\text { using fossil fuels (other than coal) and having a } \\
\text { capacity of } 10 \text { megawatts or more, with or } \\
\text { without transmission line. }\end{array}$ & $\begin{array}{l}\text { Likely to be matched to } 7(x) \text { - the clearing of } \\
\text { vegetation on any land or the breaking up of any land } \\
\text { for any purpose of an area exceeding } 50 \text { ha. }\end{array}$ \\
\hline $\begin{array}{l}\text { Construction of combined cycle power station, } \\
\text { with or without transmission line. }\end{array}$ & As above \\
\hline $\begin{array}{llll}\text { (c) } & \begin{array}{l}\text { Construction of transmission } \\
\text { environmentally sensitive area. }\end{array} & \text { line } & \text { in } \\
\end{array}$ & As above \\
\hline \multicolumn{2}{|l|}{$\begin{array}{l}\text { 11. Power Generation and Transmission (Second } \\
\text { Schedule) }\end{array}$} \\
\hline $\begin{array}{l}\text { (a) Construction of coal fired power station and } \\
\text { having the capacity of } 10 \text { megawatts or more with } \\
\text { or without transmission line. }\end{array}$ & $\begin{array}{l}\text { Likely to be matched to } 7(\mathrm{x}) \text { - the clearing of } \\
\text { vegetation on any land or the breaking up of any land } \\
\text { for any purpose of an area exceeding } 50 \text { ha. }\end{array}$ \\
\hline $\begin{array}{l}\text { (b) Construction of nuclear-fuel power station with } \\
\text { or without transmission line. }\end{array}$ & As above \\
\hline 15. Construction of Dam (Second Schedule) & $\begin{array}{l}\text { 4. Activities which may pollute inland water or affect } \\
\text { sources of water supply }\end{array}$ \\
\hline $\begin{array}{l}\text { (a) Construction of dam or impounding reservoir for } \\
\text { the purpose of irrigation, flood mitigation, control } \\
\text { of siltation, recreational, water supply or any } \\
\text { other reason with surface area of } 100 \text { ha or more. }\end{array}$ & $\begin{array}{l}\text { Likely to be matched to } 4 \text { (ii) - construction of dams, } \\
\text { artificial lakes or reservoirs with a surface area of } 50 \\
\text { hectares for impounding of water and / or } 4 \text { (iii) - } \\
\text { irrigation schemes covering an area exceeding } 1000 \text { ha. }\end{array}$ \\
\hline $\begin{array}{l}\text { (b) Dam and hydro-electric power scheme with } \\
\text { either or both of the following: } \\
\text { i. Dam of } 15 \mathrm{~m} \text { or more in height and ancillary } \\
\text { structures covering a total area of } 40 \text { ha or } \\
\text { more. } \\
\text { ii. Reservoir with a surface area of } 100 \text { ha or } \\
\text { more. }\end{array}$ & $\begin{array}{l}\text { Likely to be matched to } 7(x) \text { - the clearing of vegetation } \\
\text { on any land or the breaking up of any land for any } \\
\text { purpose of an area exceeding } 50 \text { ha. }\end{array}$ \\
\hline
\end{tabular}

\section{Methodology}

This case study aims to highlight the implications associated with co-existence and implementation of the State and Federal EIA legislations in Sarawak and suggest improvement to implementation of both legislations. It adopts a blend of literature review and qualitative approach to achieve its objectives.

Literature review involved desktop study of current EIA practices in Sarawak, the legislations governing the practices and the associated administrative processes. The qualitative survey involved semi-structured interview with a small population of practicing EIA consultants to gather their perceptions and opinions of the EIA practices (Bogdan, 2006). Five EIA consultants had volunteered to share their experiences and opinions in this matter. An outline of the methodology is shown in Figure 1.

Interviews with the EIA consultants were carried out in March 2017. The respondents consisted of three senior EIA consultants and two consultants at managerial positions. One of the senior consultants has considerable environmental auditing. Accounts of the respondents were validated by means of triangulation involving comparison of the information given by the respondents to determine the similarity and differences in the responses given for the same survey domains. To achieve triangulation, respondents at different positions from two different environmental consultant firms were selected and were interviewed separately (Bogdan, 2006). Recommendations were subsequently made to improve the implementations of both EIA legislations in Sarawak. 
Problem Identification via Researcher's EIA

Experience and Preliminary Interview with EIA Consultants

\begin{tabular}{|c|}
\hline Literature review of EIA practices, legislations and \\
administration \\
\hline $\begin{array}{c}\text { Qualitative survey via semi-structured interview with } \\
\text { EIA consultants }\end{array}$ \\
Analysis and triangulation of literature review and \\
qualitative survey findings \\
\hline $\begin{array}{c}\text { Recommendations for improvement in co- } \\
\text { implementation of the State and Federal EIA } \\
\text { legislations }\end{array}$
\end{tabular}

Figure 1: Methodology outline

\section{Discussion}

The senior EIA consultants have in their career, faced uncertainty in determining whether an EIA falls under the State or the Federal jurisdiction. A senior EIA consultant expressed that it is unclear if earthwork activities for development of industrial area nearby or within environmentally sensitive areas are regulated by the DOE or the NREB. The State EIA Order requires EIA for development of industrial estates housing medium to heavy industries (NREB, 1994). The Federal EIA Order also requires PEIA for industrial estate development under Item 17 of its First Schedule and DEIA for development in environmentally sensitive area under Item 12 of its Second Schedule (DOE, 2007). The Federal legislation does not impose implementation of Items 17 and 12 in Sarawak due to overlapping EIA requirements but explicitly requires EIA for industrial activities. However, it is difficult to separate industrial activities from earthworks to prepare site for the activities. In few instances of industrial activities, as reflected by another senior consultant, EIA for earthworks was submitted to the NREB and that for construction and operation was submitted to the DOE. DOE had later, in few instances of its review panel meeting commented that EIA submitted to the agency should also include earthworks and was unaware that an EIA for earthwork had been submitted to the State environmental agency.

One of the managers interviewed affirmed that the DOE had, in numerous instances of its feedback, required inclusion of earthworks in the EIA of industrial activities and port development, particularly erosion and sediment control plans (ESCPs). The reason is ESCPs are not warranted by the NREB but they are mandatory in EIA reports submitted to the DOE (DOE, 2007; DOE, 2011). Another manager mentioned that it is common in fast-tracked EIA for industrial activities where development is expedited via submission and approval of EIA for earthworks associated with the activities to the NREB. Nonetheless, the DOE would require the gap to be addressed when EIA for construction and operation of the industrial development is submitted subsequently. The senior consultant with auditing experience explained that environmental audit is a requirement under Section 33A EQA 1974 (Amendment 1996) to determine compliance of a development to environmental legislative requirements and environmental risks of industrial premises (DOE, 2011). It is integral to the environmental management system of a company. He recalled environmental auditing of projects under the DOE would call for ESCPs of earthworks conducted (Vun, 1999). Nonetheless, as the EIA for earthworks had been submitted to the NREB without ESCPs, this could lead to noncompliance and the clients did not relish the idea of having to conduct ESCPs to meet the audit requirement due to cost implications and the preconception that they had already fulfilled the State environmental requirement.

The manager also highlighted an area of potential confusion in aerodrome development. Prior to the implementation of the EQ (Prescribed Activities) (EIA) Order 2015, construction of airports with airstrips less than $2.5 \mathrm{~km}$ is under the governance of the NREB, as long as the airports do not fall in the area of national parks. Currently, extension and construction of aerodromes with runway $1 \mathrm{~km}$ and above or within environmentally sensitive areas are regulated by the DOE. The manager who also involves in EIA costing, added that this creates repercussion on clients' budgeting as the EIA costing could be significantly different due to the differences in scopes and technical coverage required by the DOE and the NREB. The DOE requires DEIA for construction of an airport with runway $1 \mathrm{~km}$ and above which is 
usually more comprehensive and extensive than the EIA otherwise required by the NREB prior to 2015 (NREB, 1995; DOE, 2007). A senior consultant explained that a lack of clarity in the State and Federal environmental jurisdiction can cascade to post-EIA monitoring, affecting the effectiveness of environmental protection.

The senior consultant with auditing experience expressed satisfaction with the methodology used by the DOE for environmental audits currently and added that he has also experienced audits for ISO 14001 which is directly under the governance of the ISO. He is contended with the ISO auditing standard and is of the opinion that localizing the ISO standard can be counterproductive as the effectiveness of environmental management system (EMS) lies ultimately on public environmental awareness and the efficiency of legal enforcement.

\section{ReCOMmEndATIONS}

There are few areas of apparent discord between the State and Federal environmental requirements, particularly concerning earthworks for activities requiring DEIA under the DOE's jurisdiction. In few instances mentioned above, information concerning EIA for earthworks may not be effectively conveyed to the stage of a prescribed activity requiring EIA for its construction and operation. To mitigate this shortcoming, the information can be explicitly written in the EIA report submitted to the DOE and made known by a well-informed NREB representative in the review panel meeting. Having said that, involvement of both agencies in the review of one another's EIA reports is crucial. Similarly, both agencies should be involved in scoping exercises where doubts concerning jurisdiction of EIA are encountered.

Disparity in the requirements for ESCPs can be minimized by making ESCPs a standard requirement of both environmental agencies for earthworks, though this will probably increase the cost of an EIA report submitted to the NREB, as told by one of the managers interviewed. It is suggested by a senior consultant that a project-based approach to EIA custody instead of a stage-based approach could simplify the administrative process. For example, if a project falls under the jurisdiction of the DOE, then the DOE will oversee all stages of the project from site clearing to operation and decommissioning.

In addition, a senior consultant expressed that a lack of communication is also perceived at agency-level. She mentioned few instances where regional DOE officers attended meetings with regional authorities on behalf of the State DOE representative in-charge of an EIA and the regional officers seemed not to have adequate knowledge about the EIA. She suggested that effective communication could be established between the DOE's headquarter, the State and the regional DOE offices.

Revision of the existing EIA legislations, involving both the State and Federal stakeholders is another potential measure to enhance harmonization of the State and Federal EIA legislations. In 2015, the EQ (Prescribed Activities) (EIA) Order 1987 has been revoked and replaced by the EQ (Prescribed Activities) (EIA) Order 2015. The new Order spells out prescribed activities which are applicable to the State of Sarawak. Despite, issues related to EIA for earthworks still remain. In view of this, future revision of either the State or the Federal EIA legislation can look into more clearly defined prescribed activities which allow clear identification of the agencies taking charge of the EIA.

\section{CONCLUSION}

EIA is a planning tool used to identify, predict, evaluate and mitigate the environmental effects of development projects (IAIA, 1999). In Sarawak, EIA is governed by both the State and the Federal environmental agencies under the Natural Resources and Environment (Prescribed Activities) Order 1994 and the Environmental Quality (Prescribed Activities) (Environmental Impact Assessment) Order 2015 respectively. Prescribed activities defined in both legislations are largely similar but the level of detail differs with the former having an inclusive approach while the latter being more specific. The Federal EIA Order 2015 specifies the prescribed activities under its governance in Sarawak without making explicit exclusion of its jurisdiction on other prescribed activities under the governance of the State EIA Order. In the revoked Federal EIA Order 1987, such exclusion was made clear in a clause stating that the Order was not applicable to Sabah and Sarawak in certain prescribed activities. The co-existence of both EIA Orders in Sarawak results in some level of uncertainty in determining the environmental agencies which assume authority over an EIA, particularly in instances where site clearing and earthworks for prescribed activities under the Federal EIA Order are involved. Site clearing and earthworks for the prescribed activities mentioned often require a separate EIA report to be submitted to the State environmental agency, i.e. the NREB. Furthermore, the Federal and State environmental agencies have different requirements for EIA conducted on earthworks, particularly in the undertaking of an ESCP.

Environmental auditing mandated by the Federal environmental agency (DOE) demands an ESCP for earthworks, which may not be available should the EIA report for earthworks be submitted to the NREB. Administrative complications resulted from the co-existence of both EIA Orders may have an impact on the cost of an EIA, 
particularly in the event where an EIA which has already been determined to be under the authority of an environmental agency is later transferred to or found to be under the jurisdiction of the other. This also indicates a potential shortcoming in the determination of an EIA's custody which potentially stems from a lack of consultation and communication between the environmental consultants and the environmental authorities. This highlights the importance of consultation, involvement and communication of all stakeholders in defining the custody of an EIA and streamlining the administrative process. The ultimate aim of environmental protection through synergy and cooperation should be upheld. Further research can investigate the implications of the co-existence of both EIA Orders on post-EIA monitoring. Having known the implications, a comparative study on perceived effectiveness of the State and the Federal EIA Orders is suggested.

\section{REFERENCES}

Bogdan, R. C., \& Biklen, S. K. (2006), Qualitative Research in Education: An Introduction to Theory and Methods, Allyn \& Bacon, United Kingdom.

Briffett, C., Obbard, J. and Mackee, J. (2004), "Environmental assessment in Malaysia: A means to an end or a new beginning", Impact Assessment and Project Appraisal, Vol.22 No.4, pp.221-233.

Canter, L. (1995), Environmental Impact Assessment, McGraw-Hill, United States.

Department of Environment (DOE) (2007), Environmental Impact Assessment: Procedure and Requirement in Malaysia, Department of Environment, Putrajaya, Malaysia

Department of Environment (DOE) (2011), Environmental Audit Guidance Manual, Department of Environment, Putrajaya, Malaysia.

Emang, J. J. (2006), "Public participant in EIA process in Sarawak: Any room for improvement?", paper presented at the 4th SabahSarawak Environmental Convention, 5-7 September 2006, Kota Kinabalu, Sabah, Malaysia.

Environmental Quality (Prescribed Activities) (Environmental Impact Assessment) Order 1987 (Apr 1, 1988).

Environmental Quality (Prescribed Activities) (Environmental Impact Assessment) Order 2015, P.U. (A) 195 of 2015 (Aug 5, 2015 ).

Ho, Y. C. (1986), “Determining projects requiring environmental assessments - Some thoughts and approaches, paper presented at the DOE/CETCEM EIA Workshop, 9-11 December 1986, Kuala Lumpur, Malaysia.

IAIA (1999). Principle of Environmental Impact Assessment Best Practice, International Association for Impact Assessment, Fango, ND.

Mamit, J. D. (1997), “Environmental impact assessment (EIA): Procedure and process in Sarawak", paper presented at the Training Course on Environment Management, 15-19 December 1997, Kota Kinabalu, Sabah, Malaysia.

Memon, P. A. (2000), "Devolution of environmental regulation: Environmental impact assessment in Malaysia", Impact Assessment and Project Appraisal. Vol.18 No.2, pp.283-293.

Moduying, V. J. (2001), “Environmental impact assessment (EIA) system in Sabah”, paper presented at the 6th Sabah Inter-Agency Tropical Ecosystem (SITE) Research Seminar, 13-14 September 2001, Tanjung Aru, Sabah, Malaysia.

Natural Resources and Environment Board (NREB) (1994), Natural Resources and Environment (Prescribed Activities) Order 1994, Percetakan Nasional Malaysia Berhad, Kuching.

Natural Resources and Environment Board (NREB) (1995), A Handbook of the Policy and Basic Procedure of Environmental Impact Assessment (EIA) in Sarawak, Percetakan Nasional Malaysia Berhad, Kuching.

Sentian, J. (2004), "EIA legislation in Malaysia: An overview", paper presented at the Enviro Course 2004, 17-20 May 2004, University of Malaysia, Sabah, Malaysia.

Vun, L. W., \& Latiff, A. (1999), "Preliminary ecological impact assessment and environmental impact assessment for coastal resort development in Malaysia", Impact Assessment and Project Appraisal, Vol.17, pp.133-140. 


\section{Author Biography}

Mr. Daniel Tang Kuok Ho is a lecturer of Curtin University Malaysia. He has a master degree in environmental engineering and is currently pursuing his $\mathrm{PhD}$ in the area of health and safety. He teaches environmental impact assessment, climate change and courses related to sustainability. His research interests are safety and environmental management, environmental monitoring, life cycle assessment and fuzzy logic. 